Bp Piotr Turzyński

\title{
ŚWIADECTWO DZIEWIC \\ W STAROŻYTNOŚCI \\ CHRZEŚCIJAŃSKIEJ
}

\section{The Testimony of Virgins in Ancient Christianity}

\begin{abstract}
From the very beginning, within the community of Christian believers, there have been men and women who decided to follow Christ in His celibate style of life. Virginity and sexual renunciation in the early Church had distinct meanings and motives that differentiate it from similar practices within other religions and philosophies. For early Christians, the virginal ideal constituted a special way of life in which one was dedicated wholly and permanently, with love, to God and His kingdom (which truly was believed to be at hand). The Gospel message with its eschatological calling, and the new life in Christ with its transforming power, were the ultimate sources of this remarkable phenomenon. This article tries to present the topic in three steps: a brief account of the institution of virginity in the early Church; the motivations for this special form of devotion; and the meaning and the effects of virgins' testimony. At the beginning virgins lived in their families without special tasks in the community. Gradually the importance of virginity increased. In III and IV century, virgins achieved almost the same status as martyrs had in the period of persecution. At that time virgins started to live together in monastic communities, and the great Fathers of the Church dedicated a considerable number of works to the subject. Early Christian ascetics looked backward, toward gaining a pre-Fall state of the heart, as well
\end{abstract}


as forward to their resurrection. Through the renunciation of sexuality and gender, they condemned neither, but attempted to participate in the glory of the angels. The Fathers of the Church recognized that virgins were already being made a new creation. While on this earth we are still male and female, in the kingdom of heaven, they are already one in Christ. In the writings of early fathers, quite often the value of virginity was demonstrated in comparison with the value of marriage, not in contraposition but in a simple hierarchy of value: good and better.

Keywords: Early Church, virginity, spirituality, consecrated life, monastic life

Streszczenie: Od początku istnienia Kościoła we wspólnotach chrześcijańskich pojawiają się kobiety, które darzą Chrystusa miłością oblubieńczą i ofiarują mu swoje życie. W ten sposób realizują błogosławieństwo skierowane do ludzi czystego serca i przez swoją bezżenność stają się świadkami królestwa niebieskiego. Pierwotnie żyły one w domach rodzinnych i nie posiadały jakiejś szczególnej funkcji we wspólnocie. Jednak po ustaniu prześladowań dziewice zaczęły zajmować miejsce męczenników i wraz z mnichami stały się modelem i ideałem chrześcijańskiej doskonałości. Artykuł przedstawia krótką historię instytucji dziewic w pierwotnym Kościele, pokazując rozwój w podejściu do rozumienia misji dziewic i teologii dziewictwa. Ten rozwój prowadzi od dziewictwa ukrytego w rodzinnym domu do wspólnot i klasztorów żeńskich oraz rozkwitu refleksji teologicznej na temat dziewictwa w IV w. Istotne są motywy, dla których kobiety rezygnują z małżeństwa i ofiarowują życie samemu Bogu. Być może w chrześcijańskim dziewictwie słyszany jest czasem argument z filozofii stoickiej, mówiący o trudach życia małżeńskiego, jednak najistotniejsza jest fascynacja Chrystusem i miłość wyłączna do Niego oraz szukanie bliskości Boga. Ideałem monastycznym pociągającym ludzi zanurzonych w chaosie świata stał się również wewnętrzny pokój i harmonia przypominające rajski czas ludzkości i przynoszące przedsmak przyszłego wieku i bożych przeznaczeń. Nie bez znaczenia w wyborze dziewiczej drogi życia była także tęsknota za wolnością, która realizowała się w oderwaniu od wszystkich uzależnień środowiskowych i społecznych tamtego czasu i prowadziła do oddania się tylko Bogu. Artykuł w ostatniej części chce pokazać owoce 
świadectwa dziewic. Ich sposób życia wskazuje na piękno i moc Boga, który potrafi przemienić człowieka. Najgłębsze tęsknoty ludzkiego serca zostają w nich w pewnym stopniu zaspokojone, a patrzący na nie i czerpiący $\mathrm{z}$ ich świadectwa zaglądają do świata, który przyjdzie po powszechnym zmartwychwstaniu. Dziewice przez swoją świętość i mądrość stają się ikoną macierzyńskiej płodności Kościoła i mają moc przyciągania do Chrystusa. Ponieważ w większości przypadków nie posiadają żadnych funkcji w społeczeństwie, a żyją dla Boga i na Jego chwałę, dziewice przypominają również ostateczny sens życia człowieka. U wielu autorów chrześcijańskich porównywanie dziewictwa do mistycznego małżeństwa z Chrystusem decyduje o wartości obydwu stanów życia, i małżeńskiego, i dziewiczego, co pozostaje dziedzictwem chrześcijaństwa na wieki.

Słowa kluczowe: Kościół starożytny, starożytność chrześcijańska, dziewictwo, duchowość, życie konsekrowane, życie monastyczne, monastycyzm

Pośród bogactwa form życia chrześcijańskiego istnieje od początków Kościoła bardzo cenne i przynoszące obfite owoce świadectwo dziewic. Cnota czystości obecna w życiu osób, które poszły za Chrystusem z niepodzielnym sercem w całym radykalizmie bez wątpienia ,,jest odblaskiem nieskończonej miłości łączącej trzy Boskie Osoby w tajemniczej głębi życia trynitarnego; miłości, której Słowo Wcielone dało świadectwo aż po ofiarę $z$ własnego życia; miłości, ,która rozlana jest w sercach naszych przez Ducha Świętego” (Rz 5, 5), ,przynaglającego nas, byśmy odpowiedzieli na nią całkowitą miłością do Boga i do braci" ${ }^{\prime}$. Na początku adhortacji apostolskiej Vita consecrata św. Jan Paweł II zauważa, iż poprzez wieki „,niezmienna pozostanie istota tego wyboru, który wyraża się w radykalnym darze z siebie składanym z miłości do Pana Jezusa, a w Nim do każdego członka ludzkiej rodziny. Na tym przekonaniu, które przez stulecia było natchnieniem dla wielkiej rzeszy wiernych, chrześcijański lud nadal opiera swą ufność, wiedząc, że w dorobku tych szlachetnych

${ }^{1}$ Jan Paweł II, Vita consecrata, 21. 
dusz może znaleźć bezcenną pomoc w swojej wędrówce ku niebieskiej ojczyźnie"2.

Dziewictwo, które jest formą życia ascetycznego polegającą na wyrzeczeniu się używania seksualności ${ }^{3}$, zawsze było dla Kościoła niezwykle ważnym świadectwem, że wartości ewangeliczne mogą zrealizować się w konkretnym życiu i w świecie. To świadectwo nabiera szczególnego znaczenia jednak w dzisiejszych czasach, które w wielu aspektach zostały zdominowane przez niczym nieograniczoną wolność i panseksualizm. Swiadectwo dziewic okazuje się niezwykle cenne ze względu na motywy wiary i znak miłości do Boga, któremu warto dać siebie samego i swoją czystość, ale także ze względu na istniejące w zlaicyzowanym świecie pokusy, by redefiniować małżeństwo oraz zrelatywizować miłość i relacje małżeńskie. Podejmując myśl patrystyczną, św. papież Jan Paweł II pisał w adhortacji Familiaris consortio: „Dziewictwo i celibat dla królestwa Bożego nie tylko nie stoją w sprzeczności z godnością małżeństwa, ale ją zakładają i potwierdzają. Małżeństwo i dziewictwo to dwa sposoby wyrażenia i przeżywania jedynej tajemnicy przymierza Boga ze swym ludem. Bez poszanowania małżeństwa nie może także istnieć dziewictwo konsekrowane; jeżeli płciowość ludzka nie jest traktowana jako wielka wartość dana przez Stwórcę, traci sens wyrzeczenie się jej dla królestwa niebieskiego"4.

Aby dowartościować dar dziewictwa w dzisiejszym świecie, warto zobaczyć, jak rodził się stan dziewic w Kościele, jakie motywacje przyświecały tym, którzy zachowywali dziewictwo, i ostatecznie, jakie były i są owoce świadectwa dziewic.

\footnotetext{
${ }^{2}$ Jan Paweł II, Vita consecrata, 3.

${ }^{3}$ Por. Tibiletti, ,Vergine”, 3559.

${ }^{4}$ Jan Paweł II, Familiaris consortio, 16.
} 


\section{KRÓTKI ZARYS DZIEJÓW DZIEWIC WE WCZESNYM CHRZEŚCIJAŃSTWIE}

Sam termin dziewictwo odnosi się do integralności seksualnej kobiet. Dziewicą była nazywana każda niezamężna dziewczyna mieszkająca $\mathrm{w}$ domu rodzinnym ${ }^{5}$. Początkowo dziewice, które wybierały taki stan życia, nie stanowiły odrębnej grupy o specjalnej nazwie i funkcji liturgicznej czy charytatywnej we wspólnocie Kościoła. Natomiast, jeśli chodzi o mężczyzn żyjących w czystości, to w starożytności chrześcijańskiej nazywani byli najczęściej ascetami, czy potem po prostu także mnichami prowadzącymi życie samotne lub wspólnotowe.

Warto zauważyć, że także poza chrześcijaństwem dziewictwo cieszyło się uznaniem, jako znak bliskości z bóstwem, na przykład westalki w starożytnym Rzymie, czy jako fundament porządku moralnego i autentycznych relacji małżeńskich. W różnych ruchach ascetycznych często dziewictwo było formą wstrzemięźliwości, która miała na celu uczynienie człowieka wolnym i zdolnym do panowania nad sobą i wszystkimi wymiarami swojego życia. W takim sensie, jako warunek zbliżenia do rzeczy wyższych, bożych i świętych, dziewictwo uzyskało nawet charakter sacrum. Wiele bogiń ze świata mitologii greckiej i rzymskiej było uważanych za dziewice. Takie dziewictwo nie miało jednak charakteru, tak jak później w chrześcijaństwie, religijnego, ale chodziło w nim raczej o wieczną młodość, kwitnącą witalność oraz nieskazitelność. To w chrześcijaństwie, według kardynała Tomasza Špidlika, dziewictwo zyskuje aspekt ściśle religijny, jest darem składanym dobrowolnie Bogu z miłości i jest związane $\mathrm{z}$ wewnętrzną wolnością, jako kondycją niezbędną do tego, by zjednoczyć się z Bogiem i służyć innym ${ }^{6}$.

W Starym Testamencie dziewictwo nie było w najwyższej cenie, gdyż płodność była uważana za Boże błogo-

${ }^{5}$ Por. Małunowiczówna, „Dziewica”, 604.

${ }^{6}$ Por. Špidlik - Tenace - Čemus, Il Monachesimo, 77. Zob. Kania, „Doktor dziewictwa”, 134-135. 
sławieństwo, natomiast jej brak - za rodzaj Bożej kary i wstyd wobec ludzi (Rdz 30,1; $1 \mathrm{Sm} \mathrm{1,5-6;} \mathrm{Łk} \mathrm{1,} \mathrm{25).}$ Przykładem jest córka Jeftego z Księgi Sędziów, która wobec śmierci chce opłakiwać swoje dziewictwo (Sdz 11,37). Jednak obok tego starotestamentowego głównego nurtu znajdziemy także przypadek Judyty, której wstrzemięźliwość jest prezentowana jako osobisty wybór o wartości religijnej (Jdt 8,4; 16,22). Chrześcijaństwo wnosi do rozumienia dziewictwa istotne zmiany. Chrystus wyraźnie mówi o bezżennych, którzy wybrali taką drogę ze względu na królestwo niebieskie (Mt 19,11-12). Sam wybiera drogę czystości i wśród błogosławieństw wymienia ludzi czystego serca, którzy ze względu na swój stan życia Boga oglądać będą (Mt 5,8). Ma tu swoje znaczenie także przykład życia św. Jana Chrzciciela nazwanego ,przyjacielem Oblubieńca", który raduje się głosem Oblubieńca (J 3,29).

Pierwsi chrześcijanie byli przekonani, że dziewictwo dotyczy całego Kościoła, który jest Oblubienicą Chrystusa. Św. Paweł pisze do Koryntian, że poślubił ich Chrystusowi jako czystą Dziewicę (2 Kor 11,2). Bez wątpienia szczególne znaczenie ma w rozumieniu dziewictwa w chrześcijaństwie także osoba Maryi, Dziewicy i Matki Boga zarazem. W Niej reprezentowane są wszystkie dziewice, czyli kobiety bez dzieci, które według Starego Przymierza znajdują się w sytuacji upokorzenia wobec ludzi, ale dzięki Maryi i Jej Bożemu Macierzyństwu zostają podniesione i mogą mieć udział w niezwykłej duchowej płodności Kościoła Matki. Maryja Dziewica staje się błogosławieństwem dla całej ludzkości dzięki połączeniu dziewictwa i Boskiego macierzyństwa, do którego zostaje wybrana i na które się zgadza swoim fiat ${ }^{7}$. Orygenes zauważa, że Chrystus jest paradygmatem dziewictwa dla mężczyzn, a Maryja - dla kobiet ${ }^{8}$.

W połowie II w. wyrzeczenie się pożycia seksualnego zaczyna odgrywać ważną rolę w życiu wielu wspólnot

${ }^{7}$ Por. Špidlik - Tenace - Čemus, Il Monachesimo, 80.

${ }^{8}$ Por. Orygenes, Komentarz do Ewangelii wedlug Mateusza 10, 17 (SC 162, 123; ŹMT 10, 62). 
chrześcijańskich ${ }^{9}$. Tertulian mówi o dwojakim dziewictwie: od urodzenia i od chrztu ${ }^{10}$. Trzeba zauważyć, że od początku chrześcijaństwa istniały dziewice, które były rozpoznawane przez Kościół jako ważny element życia wspólnoty, podobnie jak stan wdów ${ }^{11}$, a ze względu na wartość swojego świadectwa są stawiane zaraz po męczennikach, którzy dali świadectwo Zbawicielowi, przelewając za Niego krew $^{12}$. Św. Justyn pisze w I Apologii: „Żyją liczni mężczyźni i liczne kobiety sześćdziesięcioletni i siedemdziesięcioletni, którzy pouczeni nauką Chrystusa od dzieciństwa żyją w czystości, i szczycą się tym, że takich właśnie ludzi mógłbym wskazać właściwie z każdego stanu"13. Peter Brown jest przekonany, że ascetyzm kobiecy i wyrzeczenie się aktywności seksualnej wyrosło przede wszystkim w chrześcijańskim domu ${ }^{14}$. Chrześcijanie uważali, że rodzina i wspólnota odnoszą realne korzyści i otrzymują łaski z pobożności i formy życia dziewiczej córki i kobiety. Początkowo dla takich dziewic nie było przestrzeni życia poza domem. Opuszczały one domowe bezpieczeństwo ewentualnie tylko po to, by brać udział w uroczystościach liturgicznych wspólnoty chrześcijańskiej. Wydaje się jednak, że w Kościele starożytnym dokonuje się pewnego rodzaju ewolucja w podejściu do dziewic. Tertulian, powołując się na Biblię, uważa, że dziewice nie doznają takiego samego zaszczytnego traktowania jak wdowy ${ }^{15}$. Wdowa, według niego, rezygnuje $\mathrm{z}$ tego, co poznała i u niej nagrodzony będzie wysiłek, natomiast dziewica wyrzeka się tego, czego nie zna, więc u niej zasadniczo wynagrodzona byłaby łaska $^{16}$. Tertulian, chociaż nie definiuje i nie precyzuje języka, to jednak używa sformułowań virgo sancta, status

\footnotetext{
${ }^{9}$ Por. Brown, Ciało i spoleczeństwo, 13.

${ }^{10}$ Por. Tertulian, Zachęta do czystości 1, 4 (CSEL 70, 127; PSP 29, 165).

${ }^{11}$ Por. Tibiletti, ,Vergine”, 3560.

${ }^{12}$ Por. Calabuig - Barbieri, Verginità.

13 Justyn, I Apologia 15, 6 (PG 6, 335).

${ }^{14}$ Por. Brown, Ciało i społeczeństwo, 279.

${ }^{15}$ Por. Tertulian, Do żony 1, 8, 1 (CSEL 70, 102; PSP 29, 147).

${ }^{16}$ Tertulian, Do żony 1, 8, 2-3 (CSEL 70, 103; PSP 29, 148).
} 
virginis, sponsa Christi, votum continentiae, które wejdą do języka Kościoła ${ }^{17}$. Kilkadziesiąt lat później korzystający z myśli Tertuliana św. Cyprian z Kartaginy będzie już stawiał dziewice przed wdowami ${ }^{18} \mathrm{i}$ da świadectwo wielkiego uznania dla świadectwa stanu dziewic. W dziele $O$ stroju dziewic napisze:

Teraz mamy mówić do dziewic, o które tym większa jest troska, im wznioślejsza ich chwała. Kwiat to jest kościelnej latorośli, wdzięk i ozdoba łaski duchowej, wesołe usposobienie, całe i nieskażone dzieło chwały i czci, obraz Boga, odpowiedni do świętości Pana, piękniejsza część trzody Chrystusowej. Cieszy się przez nie i kwitnie w nich obficie chwalebna płodność matki Kościoła, o ile więcej bogate dziewictwo do liczby swej dodaje, o tyle wzrasta radość matki ${ }^{19}$.

W III w. otrzymujemy już obfite informacje o istnieniu instytucji dziewic w Afryce Północnej, Egipcie, Syrii i Palestynie oraz w Azji Mniejszej ${ }^{20}$. Do takiej grupy wchodziło się przez przyrzeczenie dozgonnej czystości. Początkowo dziewice składały przyrzeczenia prywatne wobec starszych Kościoła, ale z biegiem czasu upowszechnił się ślub publiczny. Powstała więc grupa wyodrębniona z ogółu wiernych, posiadająca swoją tożsamość i wymieniana tuż po duchowieństwie. Dziewice były umieszczane w katalogach Kościoła lokalnego jako osoby uprawnione do specjalnych modlitw wstawienniczych i do korzystania z pomocy charytatywnejej ${ }^{21}$ Przednicejscy Ojcowie Kościoła mówią już o związku dziewic z Kościołem. One w Kościele się rodzą i od Kościoła otrzymują swój duchowy profil. Dziewica, która jest córką Kościoła, od niego otrzy-

${ }^{17}$ Por. Metz, La consécration, 50-55.

${ }^{18}$ Por. Cyprian z Kartaginy, List 55, 20, 2 (CSEL 3, 2, 638; PSP $1,143)$.

${ }^{19}$ Cyprian z Kartaginy, O stroju dziewic 3 (CSEL 3, 1, 189; POK 19, 137).

${ }^{20}$ Por. Małunowiczówna, „Dziewica”, 604.

${ }^{21}$ Por. Małunowiczówna, „Dziewica”. 
muje potrójną charakterystykę: jest dziewicą, oblubienicą i matką w duchowym wymiarze ${ }^{22}$.

W IV w. dziewictwo zaczęło zajmować poważne miejsce w refleksji teologicznej i pojawiła się na jego temat bardzo bogata literatura. $\mathrm{O}$ dziewictwie piszą między innymi: Metody z Olimpu ${ }^{23}$, Bazyli z Ancyry ${ }^{24}$, Bazyli Wiel$\mathrm{ki}^{25}$ i Hieronim ${ }^{26}$ obydwaj w listach do mniszek i mnichów, Grzegorz z Nazjanzu ${ }^{27}$, Grzegorz z Nyssy ${ }^{28}$, Ewagriusz z Pontu ${ }^{29}$, Jan Chryzostom ${ }^{30}$, Ambroży ${ }^{31}$, Augustyn ${ }^{32}$ i wielu innych pisarzy i Ojców Kościoła. Wtedy także powstały klasztory żeńskie. W Egipcie przy św. Pachomiuszu powstały wspólnoty kobiet prowadzone przez jego siostrę Marię, a w Betlejem pod duchową opieką świętego Hieronima zaczęły istnieć klasztory żeńskie.

Zasadniczo właśnie w IV w. nastąpił poważny przełom w formie życia dziewic. Zamiast żyć wśród ludzi, zaczęły one tworzyć wspólnoty i klasztory, w których realizowały razem swoje dziewicze życie oddane Bogu ${ }^{33}$. Życie wspólnotowe bez wątpienia pomagało w zachowaniu i pielęgnowaniu czystości. Św. Hieronim nauczał, że mnisi, dziewice i kapłani przez swoją czystość i wstrzemięźliwość strzegą wspólnoty Kościoła ${ }^{34}$. Na przełomie 383 i 384 r. napisał on

${ }^{22}$ Por. Calabuig - Barbieri, Verginità.

${ }^{23}$ Zob. Metody z Olimpu, Uczta (PG 18, 27-228; PSP 24, 27-108).

${ }^{24}$ Zob. Bazyli z Ancyry, O dziewictwie (CPG 2, 2825-2827).

${ }^{25}$ Zob. Bazyli Wielki, O dziewictwie (PG 30, 669-809).

${ }^{26}$ Zob. Hieronim, Listy do Eustachium (CSEL 54; ŹM 33).

${ }^{27}$ Zob. Grzegorz z Nazjanzu, O pochwale dziewictwa (PG 37, 521-573); Nauki dla dziewic (PG 37, 573-632); Do dziewic (PG 37, 640-642).

${ }^{28}$ Zob. Grzegorz z Nyssy, Życie Św. Makryny (PG 46, 959-1000) (tt. W. Kania, 387-404); O dziewictwie (PG 46, 317-416).

${ }^{29}$ Zob. Ewagriusz z Pontu, Napomnienie dla dziewicy (CPG 2436; ŹM 18, 301-306).

${ }^{30}$ Zob. Jan Chryzostom, O dziewictwie (PG 48, 533-596).

${ }^{31}$ Zob. Ambroży, O dziewictwie (PL 16, 279-316).

${ }^{32}$ Zob. Augustyn, $O$ świętym dziewictwie (CSEL 41, 233-343; ŹM 27, 271-350).

${ }^{33}$ Por. Kłoczowski, Od pustyni, 81.

${ }^{34}$ Por. Heid, Celibat $w$ Kościele pierwotnym, 137. 
w Rzymie list do Eustachium córki św. Pauli, która właśnie pod wpływem Hieronima rozpoczęła życie ascetyczne z miłości do Chrystusa czystego, ubogiego i posłusznego. List został zatytułowany $O$ zachowaniu dziewictwa i jest prawdziwą rozprawą teologiczną i ascetyczną o dziewictwie zachowanym ze względu na królestwo niebieskie. Autor ukazuje trudy związane z życiem w czystości, ale równocześnie zachęca, by Eustachium na wzór Abrahama opuściła dotychczasowy styl życia oraz, korzystając także z własnego doświadczenia wewnętrznej walki, daje adresatce duchowe rady ku zachowaniu czystości ${ }^{35}$.

\section{MotyWY WYBORU DZIEWICTWA}

Dziewictwo w pismach Ojców Kościoła posiada przede wszystkim motywację biblijną i jest włączone w historię zbawienia, od której otrzymuje znaczenie i sens ${ }^{36}$. Królestwo Boże, do którego zmierza historia, realizuje się już w osobie dziewiczego Jezusa Chrystusa. Kto zobowiązuje się do dziewictwa równocześnie harmonizuje się z królestwem Boskiego Oblubieńca. Dziewictwo jest z jednej strony realizacją królestwa zapoczątkowanego w Chrystusie, a z drugiej - zapowiedzią przyszłego wieku, w którym nie będą się żenić ani za mąż wychodzić (Mt 22,30). W chrześcijaństwie starożytnym jest więc dziewictwo początkiem i proroctwem szczęśliwej wieczności, a przez to, w ujęciu niektórych autorów, posiada wyższość nad małżeństwem. Pisarze chrześcijańscy, zalecając stan dziewictwa, czasem na początku używali zapożyczonego z filozofii stoików argumentu o trudach małżeństwa, wskazując na liczne troski o dzieci, na niełatwą sytuację kobiety, która w mężu musi uznać swego pana ${ }^{37}$. Ostatecznie taka motywacja nie jest wystarczająca, bowiem istotna jest wiara w Boga i ofiara

${ }^{35}$ Por. Degórski, „Wstęp”, 61-62.

${ }^{36}$ Por. Tibiletti, ,Vergine”, 3561.

${ }^{37}$ Por. Augustyn, Wyznania 9, 9, 19 (CSEL 33/1, 213; tł. Z. Kubiak, 241); Zob. Tibiletti, ,Vergine”, 3562. 
składana na Jego cześć i z miłości do Niego. Św. Ambroży w dziele $O$ dziewictwie bardzo mocno podkreśla naturę wewnętrzną i duchową dziewictwa, które jest przyjęte $\mathrm{z}$ miłości do $\mathrm{Boga}^{38}$. Odczytując ewangeliczną pochwałę „czystości serca”, biskup Mediolanu ponad nienaruszalność fizyczną ciała dziewic stawia dziewictwo duchowe, ponieważ czystość niszczy w sobie ten, kto „pożądliwie patrzy na kobietę" (Mt 5,28) ${ }^{39}$. Augustyn z kolei podkreśla, że: „dziewictwo nie jest otaczane czcią dla siebie samego, ale dlatego, że jest poświęcone Bogu" ${ }^{40}$. Jest on przekonany, że nie można nazywać prawdziwie czystym tego, kto nie praktykuje tej cnoty ze względu na prawdziwego Boga i dla Boga ${ }^{41}$. Do dziewic biskup Hippony pisze, że mają być piękne nie pięknem cielesnym, ale pięknem wewnętrznym, pięknem obyczajów ${ }^{42}$.

Bez watpienia ideał dziewictwa w przekonaniu chrześcijańskich pisarzy służył bliskości Boga. Tertulian jest przekonany, że rezygnując z używania seksualności, człowiek zdobywa smak rzeczy duchowych, a w ostateczności Ducha Świętego ${ }^{43}$. „To w głębi swego ducha człowiek rzuca się w obecność Bożą, a niewinność jest tylko jednym z imion oblubieńczej tajemnicy Baranka"44. Czystość i dziewictwo wynosi człowieka z niepokojów i wewnętrznego rozdarcia, a nawet czasem z piekła do królestwa Boga, co stanowi drogę pokonaną już przez zwycięskiego Chrystusa. Czystość jest więc wewnętrznym wyniesieniem do bliskości Boga.

${ }^{38}$ Por. Ambroży, O dziewictwie 13 (PL 300).

${ }^{39}$ Por. Ostrowski, Obrona dziewicy, 791.

${ }^{40}$ Augustyn, $O$ świętym dziewictwie 8, 8 (CSEL 41, 241; ŹM 27, 280).

${ }^{41}$ Por. Augustyn, Małzeństwo i pożadliwość 1, 3, 4 (CSEL 42/2, 211) (tł. K. Kościelniak, 345).

${ }^{42}$ Por. Augustyn, $O$ świętym dziewictwie 55, 56 (CSEL 41, 301; ŹM 27, 340).

${ }^{43}$ Por. Tertulian, Zachęta do czystości 10, 11 (CSEL 70, 132; PSP 29, 165).

${ }^{44}$ Evdokimov, Wieki życia, 175. 
W myśli teologicznej dziewictwo łączone jest z życiem anielskim. Pisze o tym wprost św. Cyprian z Kartaginy:

Zachowajcie, dziewice, zachowajcie to, czym być zaczęłyście. Zachowajcie, czym będziecie. [...] Czym my mamy być, wy już być zaczęłyście. Wy chwałę zmartwychwstania już na tym świecie posiadacie, [...] gdy trwacie w czystości i dziewictwie, jesteście równe aniołom Boga $\mathrm{Ba}^{45}$.

Istnieje powszechne przekonanie wśród pisarzy chrześcijańskich, że „dziewictwo, antycypując [...] stan post mortem, zapewnia nieskazitelność i nieśmiertelność" ${ }^{46}$. Jest ono powrotem do raju, do stanu Ewy przed grzechem, a poprzez wyeliminowanie zjednoczenia cielesnego i właśnie przez nieskazitelność i nieśmiertelność człowiek staje się równy aniołom, co jest naturalną tęsknotą ludzkiego serca. Niemal we wszystkich wskazówkach duchowych powraca ideał apathei jako stanu wewnętrznego pokoju i panowania nad namiętnościami i poruszeniami duszy ${ }^{47}$. W myśli wschodniej mnisi i mniszki żyjący ślubem czystości są nazywani ,ziemskimi aniołami i niebiańskimi ludźmi", stając się żywą ikoną Boga i mocą łaski nowym stworzeniem $^{48}$. Jednym $z$ kluczowych zagadnień związanych z motywacją dziewictwa w tekstach Ojców Kościoła jest teologia stworzenia i teologia ludzkiej seksualności. Upadek pierwszych rodziców zaburzył pierwotną harmonię i pokój oglądania Boga ${ }^{49}$. Życie według ideału monastycznego w czystości jest, w przekonaniu Ojców Kościoła, życiem anielskim, gdyż przynajmniej w tęsknocie i wysiłku jest przebywaniem w niebie, które jest ojczyzną człowieka ${ }^{50}$. Życie dziewic ma charakter niebiański, ponieważ przede wszystkim jest życiem w obecności Boga

\footnotetext{
${ }^{45}$ Cyprian z Kartaginy, O stroju dziewic 22 (CSEL 3, 203; POK

${ }^{46}$ Guillaumont, U źródeł monastycyzmu chrześcijańskiego, II, 223.

47 Por. Calabuig - Barbieri, Verginità.

48 Por. Evdokimov, Wieki życia, 157.

49 Por. Kidd, The Virgin Desert.

${ }^{50}$ Zob. Flp 3,20 („Nasza bowiem ojczyzna jest w niebie”).
} $19,145)$. 
i w całkowitym oddaniu się Jego chwale w „kosmicznej liturgii" uwielbienia ${ }^{51}$.

Pośród motywów podjęcia dziewiczego życia nie bez znaczenia była także kwestia wolności. Zwłaszcza życie na pustyni było często podejmowane w poszukiwaniu zewnętrznej i przede wszystkim wewnętrznej wolności. Chodziło o wolność od niewolnictwa, zależności, wyzysku i posiadania oraz od namiętności. W świecie starożytnym kobiety na ogół nie miały wielkiej kontroli nad własnym życiem, a często także nad własnym ciałem. Zazwyczaj były niejako własnością ojców, mężów i panów, jeśli były niewolnicami. Wyjście na pustynię dawało im możliwość odrzucenia tego ograniczenia. Tutaj mogły jako dziewice żyć, troszcząc się jedynie o królestwo Boże, ,nie poddając się mocom i okolicznościom świata" 52 . Szczególne znaczenie miała wolność od namiętności, które niepokoją serce i wprowadzają nieporządek do duszy. O wolności od namiętności mówili stoicy, a podjął tę ideę Ewagriusz z Pontu, potem pisał o niej Hieronim, natomiast Jan Kasjan nazywał ją „,czystością serca" ${ }^{33}$. W takim ideale człowiek zbliża się do wolności Boga, w którym nie ma namiętności. O stanie wolności pisał Klemens Aleksandryjski w Kobiercach:

Gnostyk, więc i człowiek doskonały, powinien być wyzbyty, naszym zdaniem, wszelkiego psychicznego afektu. Gnoza bowiem wypracowuje samoopanowanie, a samoopanowanie z kolei wytwarza biegłość czy dyspozycję. Ta z kolei postawa powoduje stan niewrażliwości na afekty, a nie stan umiarkowania w afektach. Stan niewrażliwości na afekty jest bowiem owocem wszechstronnego wyrwania z gruntu duszy chwastów pożądania ${ }^{54}$.

Dziewica oddana Bogu w Nim zyskiwała wolność, która stanowi harmonię wszystkich władz, wewnętrzny

${ }^{51}$ Por. Bouyer, Il senso, 69.

${ }^{52}$ Chryssavgis, W sercu pustyni, 85.

${ }^{53}$ Por. Desprez, Poczatki monastycyzmu, I, 182.

${ }^{54}$ Klemens Aleksandryjski, Kobierce 6, 9, 74, 1 (GCS 52, 442; tt. J. Niemirska-Pliszczyńska, 155). 
spokój i jest realizacją pierwotnego zamysłu Stwórcy w stosunku do człowieka.

\section{ZNACZENIE I WPLYW ŚWIĘTYCH DZIEWIC}

Mówiąc o dziewictwie, Orygenes i wielu autorów za nim uznaje tajemnicę Trójcy Swiętej jako źródło tego wielkiego daru. Relacje w Trójcy są wyłącznie duchowe, więc równocześnie dziewicze ${ }^{55}$. Ojcowie Kościoła są przekonani, że człowiek zachowujący dziewictwo staje się świątynią Boga i sanktuarium Trójcy Świętej, a w ten sposób dokonuje się w nim powrót do rajskiego stanu życia $^{56}$. Orygenes zauważa również, że czystość pozwala Duchowi Swiętemu przemienić ciało człowieka sprawiedliwego na podobieństwo przemiany, jaka dokonała się na górze Tabor ${ }^{57}$. Grzegorz z Nyssy w traktacie $O$ dziewictwie zauważa, że człowiek popchnięty przez Ducha Świętego zbliża się do Chrystusa Ś Swiatłości i staje się świetlany ${ }^{58}$. W teologii monastycznej celem i zasadą wszelkiego postępowania był powrót do natury sprzed grzechu pierworodnego. Dziewice są więc w starożytności chrześcijańskiej świadkami Boga, Jego obecności i Jego darów. Teza, by żyć według natury, oznaczała w rzeczywistości podjęcie wysiłku ascetycznego, aby odzyskać integralność i harmonię, którą ciało i dusza człowieka posiadały, gdy wyszły spod ręki Stworzyciela. Równocześnie taka integralność i harmonia zostaną przywrócone na końcu czasów. Dziewice już na ziemi zbierają owoce zarezerwowane na czas zmartwychwstania ${ }^{59}$.

Ojcowie Kościoła często, podkreślając związek między modlitwą i dziewictwem, uznają, że dzięki temu wzniosłemu sposobowi życia człowiek jest podniesiony do kon-

${ }^{55}$ Por. Crouzel, Virginité, 46.

${ }^{56}$ Por. Špidlik - Tenace - Čemus, Il Monachesimo, 81-82.

${ }^{57}$ Por. Orygenes, $O$ zasadach 3, 6, 6 (GCS 22, 213; ŹMT 1, 315).

${ }^{58}$ Por. Grzegorz z Nyssy, $O$ dziewictwie 11, 4 (PG 46, 366).

${ }^{59}$ Por. Grzegorz z Nyssy, $O$ dziewictwie 24, 4 (PG 46, 411). 
templacji Boga, a więc do poznania Stwórcy i niezwykłej bliskości z Nim, która nazywana jest zjednoczeniem mistycznym $^{60}$. Dziewice dzięki wolności w stosunku do ciała oraz oddaniu się kontemplacji Stwórcy stają się świadkami i prorokiniami przyszłego wieku, a chociaż żyją w czasie, dotykają szczęśliwej wieczności ${ }^{61}$. W dziewiczym życiu objawia się piękno obrazu Bożego umieszczonego w człowieku w chwili stworzenia, a zabrudzonego przez grzech. Piękno tego pierwotnego obrazu posiada niezwykłą siłę przyciągania.

W pierwotnym chrześcijaństwie powszechny był ideał męczennika, który jako „zraniony przyjaciel Oblubieńca” jest „gwałtownikiem zdobywającym szturmem niebo"62. Jest on żywym obrazem Chrystusa ukrzyżowanego, a dla świata, aniołów i ludzi jest również ,widowiskiem”, które ogląda się z przejęciem jako niezwykłe świadectwo obecności Boga. W okresie spokojnej egzystencji Kościoła rolę męczenników zajęli rezygnujący ze świata i jego propozycji mnisi i dziewice. Jak to powie prawosławny teolog, miłośnik Ojców pustyni, „, chrzest krwi” robi miejsce dla „chrztu ascezy”, ofiary i wyrzeczenia ${ }^{63}$. Podobnie jak męczeństwo, dziewictwo i wstrzemięźliwość są darem Bożym. Wobec tego daru niezbędna jest postawa pokory i wdzięczności. W tekstach mówiących o dziewictwie wschodni Ojcowie Kościoła często używają słów charis, charisma, dorea, które podkreślają darmowość tego daru ofiarowanego przez Bożą miłośćc4.

Wśród Ojców zachodnich, ze względu na swoje doświadczenie życiowe i dyskusję z pelagianami, szczególnie święty Augustyn podkreśla, że zarówno małżeństwo, jak i dziewictwo są darem Bożym ${ }^{65}$. Ciekawe jest to, że wielką wartość dziewictwa Augustyn wydobywa nie przez pokazanie małej wartości małżeństwa, ale przez podkreślenie

\footnotetext{
${ }^{60}$ Por. Špidlik - Tenace - Čemus, Il Monachesimo, 83.

${ }^{61}$ Por. Špidlik - Tenace - Čemus, Il Monachesimo, 85.

${ }^{62}$ Por. Evdokimov, Wieki, 155.

${ }^{63}$ Por. Evdokimov, Wieki, 156-157.

${ }^{64}$ Por. Špidlik - Tenace - Čemus, Il Monachesimo, 92.

${ }^{65}$ Zob. Swoboda, „Aspekty teologiczne”, 139-157.
} 
piękna i dobra czystej, oblubieńczej relacji małżonków. Pisze on w dziele $O$ świętym dziewictwie:

jeśli czystość małżeńską, mimo że zachowywaną w ciele, przypisuje się nie ciału, ale umysłowi, ponieważ on stoi na straży ciała i nim kieruje, by nie łączyło się ono z żadnym innym poza własnym małżeństwem, to o ileż bardziej i zaszczytniej należy zaliczyć do zalet umysłu ową wstrzemięźliwość, w której samemu Stwórcy duszy i ciała ślubuje się czystość ciała, uświęca ją i zachowu$\mathrm{je}^{66}$.

Fakt, że dziewictwo jest darem, nie zwalnia jednak człowieka od podjęcia wewnętrznej walki o nie. Powrót do natury rajskiej sprzed upadku pierwszych rodziców, jak jest rozumiane dziewictwo, wymaga ascetycznych wysiłków w celu zaparcia się siebie, co jest „gwałtem” zadanym samemu sobie i swemu ciału poddanemu pożądliwości. W rzeczywistości autorzy chrześcijańscy, uznając przeciw gnostykom pozytywny aspekt stworzenia i ludzkiego ciała, podkreślają, że ta przemoc ukryta w wysiłkach ascetycznych skierowana jest nie tyle przeciw samemu ciału, ile przeciwko pasjom zamieszkującym w ciele ${ }^{67}$. Dziewictwo jest zawsze świadectwem wielkości daru Bożego, Jego wszechmocy, ale także świadectwem ludzkiego pragnienia i zmagania oraz walki duchowej dodanych do Bożych darów. Dziewictwo jest więc z jednej strony darem Boga dla niektórych, a z drugiej - darem, jaki człowiek czyni Bogu, nie bez własnego wysiłku i trudu. Myśl teologiczna pierwszych wieków chrześcijaństwa jest zgodna - tę niezwykłą łaskę można zachować mocą Boga i siłą modlitwy, pokory i ascezy.

Dziewice przypominały również, że celem życia nie jest pełnienie jakichś określonych funkcji w społeczeństwie $^{68}$. Stawały się świadkami innej rzeczywistości i pokazywały, iż „nie ma już Żyda ani poganina, nie ma już

${ }^{66}$ Augustyn, O świętym dziewictwie 8, 8 (CSEL 41, 241; ŹM 27, 280).

${ }^{67}$ Por. Špidlik - Tenace - Čemus, Il Monachesimo, 93.

${ }^{68}$ Por. Chryssavgis, $W$ sercu pustyni, 86. 
niewolnika ani człowieka wolnego, nie ma już mężczyzny ani kobiety, wszyscy bowiem jesteście kimś jednym w Chrystusie Jezusie" (Ga 3,28). Takie podejście, zwłaszcza w środowisku Ojców i Matek pustyni, było przynajmniej teoretycznym przeciwstawieniem się dyskryminacji kobiet, a ostatecznie nawet takie w teorii dowartościowanie kobiet było wprowadzaniem rewolucji w świecie zdominowanym przez mężczyzn ${ }^{69}$. Ideał dziewictwa pokazuje również podstawową prawdę antropologiczną, że nikt, żaden człowiek, nie jest wolny od seksualności, ale to ciało jest zróżnicowane płcią, natomiast dusza stworzona na obraz i podobieństwo Boga miłującego nie jest ani żeńska, ani męska, ponieważ jest niecielesna. $Z$ tego powodu życie duchowe i wszystkie jego praktyki, asceza, tęsknoty i ofiara, są zasadniczo takie same dla kobiet i dla mężczyzn. Takie było stanowisko zdecydowanej większości Ojców wschodnich i zachodnich ${ }^{70}$. Wydaje się jednak, że chociaż ta wizja przekracza ograniczenia epoki, która w wielu aspektach nie potrafiła dowartościować kobiety i jej geniuszu, to jednak posiada swoje ograniczenia, które niektórzy pisarze chrześcijańscy będą starali się skorygować. Zdaniem kardynała Tomasa Špidlika Ojcowie Kościoła w swojej wizji seksualności byli zbytnio ulegli teoriom platońskim $^{71}$. Tym, który próbuje uwolnić się nieco od kontekstu monastycznego w rozważaniach dotyczących małżeństwa i dziewictwa, był św. Jan Chryzostom. Potrafi on opisywać piękno chrześcijańskiej rodziny i małżeństwa, a $\mathrm{z}$ drugiej strony pisać z entuzjazmem o dziewictwie poświęconym Bogu ${ }^{72}$. Jednak mimo wszystkich ograniczeń myśli Ojców Kościoła dowartościowanie kobiety dziewicy oddanej Bogu, łączenie wartości dziewictwa z wartością małżeństwa, ale nie przez opozycję dobro i zło, lecz na zasadzie dobre - lepsze, to jest wzięty z Ewangelii zaczyn prawdy i miłości, który zaowocuje kiedyś w cywilizacji

${ }^{69}$ Por. Chryssavgis, $W$ sercu pustyni, 84.

${ }^{70}$ Por. Špidlik - Tenace - Čemus, Il Monachesimo, 88-89.

${ }^{71}$ Por. Špidlik - Tenace - Čemus, Il Monachesimo, 89.

${ }^{72}$ Zob. Maulard, Saint Jean Chrysostome. 
chrześcijańskiej chociażby w prawach osoby ludzkiej, w tym także kobiety.

Jednym z owoców istnienia stanu dziewic we wczesnym chrześcijaństwie jest fakt, że teologowie piszący o dziewictwie rozwijają bardzo ważny w teologii temat mistycznych zaślubin. Wspomnieliśmy wcześniej, że wprowadzony przez Tertuliana termin sponsa Christi $^{73}$, w odniesieniu do dziewicy chrześcijańskiej w IV w., staje się powszechny w użyciu ${ }^{74}$. Bez wątpienia dla Orygenesa, i od niego w całej tradycji teologicznej, istnieje przekonanie, że każda dusza ochrzczona jest oblubienicą Chrystusa $^{75}$, ale stopniowo zakorzenia się myśl o wyjątkowym charakterze dziewiczych kobiet, które towarzyszą Chrystusowi jako Oblubieńcowi, żyją Nim i czekają na Jego powrót ${ }^{76}$. Ponieważ relacja dziewicy z Chrystusem jest mistycznym małżeństwem, upadki cielesne są rozumiane jako bigamia i cudzołóstwo. Złamanie ślubu czystości Kościół karał dosyć surowo. Synod w Elwirze z 306 r. kobietę, która to uczyniła, wykluczał ze społeczności, a gdy podjęła pokutę mogła być przyjęta do wspólnoty Kościoła i przyjąć przed śmiercią komunię ${ }^{77}$. Synod w Ancyrze w 314 r. był nieco łagodniejszy i tego rodzaju winy karał tak jak bigamię ${ }^{78}$. Takie prawo wynikało z przekonania, że dziewica poświęcona Bogu stawała się własnością Chrystusa, jako Jemu zaślubiona ${ }^{79}$. Przez to połączenie tematów małżeńskich z ideą dziewictwa dla Boga zyskują obydwa tematy, zarówno małżeństwo, jak i dziewictwo nabierają wielkiej wartości.

Dziewictwo w chrześcijaństwie ma bardzo mocny rys chrystologiczny. Więź z Chrystusem ma tu charakter ofiary składanej Boskiemu Oblubieńcowi z miłości. Kobiety naśladują Chrystusa, idą za Nim i przez życie

\footnotetext{
${ }^{73}$ Por. Tertulian, Do żony 1, 4, 4 (CSEL 70, 98; PSP 29, 147).

${ }^{74}$ Por. Adnès, „Mariage spirituel”, 393.

${ }^{75}$ Por. Crouzel, Orygenes, 162.

${ }^{76}$ Por. Špidlik - Tenace - Čemus, Il Monachesimo, 84.

${ }^{77}$ Por. Concilium Eliberitanum can 13 (SC 241, 78; ŹMT 37, 52).

${ }^{78}$ Por. Concilium Ancyranum can 67 (SC 241, 92; ŹMT 37, 67).

${ }^{79}$ Por. Ostrowski, „Obrona dziewicy”, 793.
} 
w dziewictwie realizują się w nich ewangeliczne błogosławieństwa ${ }^{80}$. Równocześnie bardzo ważny, zwłaszcza dla św. Augustyna, jest eklezjologiczny rys dziewictwa. Ślub dziewictwa składany we wspólnocie chrześcijan łączy z Chrystusem i jest znakiem zaślubin z całym Kościołem, którego Oblubieńcem jest Chrystus. Kobiety żyjące czystością i poświęcone Bogu uczestniczą w zaślubinach Chrystusa z Kościołem i są znakiem przypominającym wiernym konieczność zachowania dziewictwa duchowego, na które składa się czystość wiary i obyczajów. Augustyn, mówiąc o Kościele jako dziewicy i matce, podkreśla, że święte dziewice rodzą się nie z płodności cielesnej, lecz właśnie z duchowej płodności wierzącej wspólnoty Kościoła $^{81}$. Równocześnie swoim świadectwem życia i mocą ofiary przyciągają do Chrystusa i są przyczyną płodności Kościoła. Klasyczne jest tu doświadczenie św. Augustyna, który poruszony przykładem mnichów egipskich żyjących ślubem czystości, zdobywa przekonanie, że można zrezygnować z używania seksualności i żyć dla $\mathrm{Boga}^{82}$.

Trzeba także zauważyć, że dziewice są połączone z tajemnicą Maryi Dziewicy, która pozostając Dziewicą, staje się Matką. Czystość ofiarowana Bogu, tak jak krew męczenników, staje się źródłem wielkiej duchowej płodności Kościoła Matki. Grzegorz z Nyssy pisze, że dziewictwo daje każdemu możliwość bycia matką Chrystusa ${ }^{83}$. Jest to temat bardzo drogi wielu Ojcom Kościoła, którzy podkreślają, iż macierzyństwo realizuje się w głębi serca przez zdobywanie mocą Ducha Świętego i własnym wysiłkiem cnót mądrości i miłości. To nowe paradoksalne macierzyństwo, które nie zależy od woli ludzkiej i nie jest związane z pożądliwością ciała, sprawia, że ustępuje zło i cierpienie, które zaciążyło nad macierzyństwem ludzkim po grzechu pierworodnym $^{84}$.

${ }^{80}$ Por. Swoboda, „Aspekty teologiczne”, 156.

${ }^{81}$ Por. Swoboda, „Aspekty teologiczne”, 156.

82 Por. Augustyn, Wyznania 8, 6, 14 (CSEL 33/1, 181; tł. Z. Kubiak, 209).

83 Por. Grzegorz z Nyssy, O dziewictwie 14, 3, 20 (PG 46, 382).

84 Por. Špidlik - Tenace - Čemus, Il Monachesimo, 82. 


\section{Podsumowanie}

Od początku chrześcijanie zachwycali się dziewiczym życiem Chrystusa, jego błogosławieństwem skierowanym do ludzi czystego serca oraz zachętą do bezżenności dla królestwa niebieskiego. W pierwotnym Kościele znajdowały się kobiety, które zachwycone Zbawicielem i darzące Go miłością, szły za Nim, ofiarowując Mu swoje życie. Początkowo żyły one w domach rodzinnych i nie odgrywały jakiejś istotnej roli we wspólnocie Kościoła. Powoli jednak, wraz z ustaniem prześladowań i rozwojem chrześcijaństwa, dziewice zaczęły zajmować miejsce męczenników i wraz z mnichami stały się ważnymi świadkami obecności Chrystusa w świecie. Ich sposób życia ukazuje przemieniającą człowieka moc Boga. W nich wypełnia się ludzka tęsknota powrotu do rajskiego stanu życia oraz pragnienie wolności od nieuporządkowanych namiętności ukrytych w duszy ludzkiej po grzechu pierworodnym. Piękno dziewictwa ofiarowanego Bogu pozytywnym aktem woli oraz wstrzemięźliwość i asceza są zwycięstwem człowieka nad tendencjami, które po upadku pierwszych rodziców są związane z ciałem i cielesnością człowieka. Natura ludzka przecież buntuje się przeciw degradacji własnej osoby do zwierzęcego i zmysłowego poziomu życia. W oczach chrześcijan dziewice żyją na świecie we wspólnocie Kościoła, ale posiadają siłę wstawienniczą, którą czerpią z bliskości Boga i w ten sposób wzywają do spojrzenia w kierunku świata, który przyjdzie. One żyją w czasie, ale dotykają wieczności.

W III i IV w. klasztor zajął miejsce rodzinnego domu, a autorytet biskupa, przed którym pierwotnie składało się ślub czystości, został zastąpiony autorytetem wspólnoty i przełożonej. W tym czasie powstało także wiele literatury ujmującej teologicznie dar dziewictwa i zachęcającej do takiej służby Kościołowi, który obficie zakwitł liliami dziewic. Relacja z Chrystusem Oblubieńcem prowadzi wiele kobiet do wielkiej mądrości i ostatecznie do świętości, które to dary z kolei decydują o macierzyńskiej płodności Kościoła i mają moc przyciągania innych. 
Świadectwo życia dziewic pozostaje zawsze aktualne, jest umocnieniem w każdym stanie życia chrześcijańskiego i zaproszeniem, na które odpowiadają także następne pokolenia. Asceza, ofiara i miłość czystych kobiet kochających Chrystusa wyłączną i niepodzielną miłością „,wywiera wpływ pedagogiczny. Najbardziej zatroskany człowiek tego świata wiedział, że zamiast niego gdzieś tam są prawdziwi ludzie, którzy w ciszy serca rozmawiają z aniołami i wdzierają się w życie przyszłego wieku" ${ }^{85}$.

\section{Bibliografia}

Adnès P., „Mariage spirituel”, Dictionnaire de spiritualité (Paris 1980) X, 388-408.

Augustyn, Malżeństwo i pożadliwość (tł. K. Kościelniak, Pisma świętego Augustyna o matżeństwie i dziewictwie, Lublin 2003).

Augustyn, O świętym dziewictwie (tł. P. Nehring) (Źródła Monastyczne 27; Kraków 2002).

Augustyn, Wyznania (tt. Z. Kubiak) (Warszawa 2002).

Bouyer L, Il senso della vita monastica (Mognano 2013).

Brown P., Ciało i spoteczeństwo. Mężczyźni, kobiety i abstynencja seksualna we wczesnym chrześcijaństwie (Kraków 2006).

Calabuig I.M. - Barbieri E., Verginità consacrata nella Chiesa, http://www.paulus.net/identita/pdf/documenti/verginita_consacrata.PDF (dostęp 17.12.2015)

Chryssavgis J., $W$ sercu pustyni. Duchowość ojców i matek pustyni (Kraków 2007).

Crouzel H., Orygenes (Kraków 2004).

Crouzel H., Virginité et mariage selon Origène (Paris 1963).

Cyprian z Kartaginy, Listy (tł. W. Szołdrski) (Pisma Starochrześcijańskich Pisarzy 1; Warszawa 1969).

Cyprian z Kartaginy, O stroju dziewic (tł. J. Czuj) (Pisma Ojców Kościoła 19; Poznań 1937).

Degórski B., „Wstęp”, Święty Hieronim, Listy do Eustachium

(tł. B. Degórski) (Źródła Monastyczne 33; Kraków 2004).

${ }^{85}$ Evdokimov, Wieki, 140. 
Desprez O.V., Początki monastycyzmu (Tyniec - Kraków 1999). Evdokimov P., Wieki życia duchowego (Kraków 1996).

Ewagriusz z Pontu, Napomnienie dla dziewicy (tł. M. Grzelak)

(Źródła Monastyczne 18; Kraków 1998).

Grzegorz z Nyssy, Życie św. Makryny (tł. W. Kania; Analecta Cracoviensia 3 [1971] 387-404).

Guillaumont A., U źródet monastycyzmu chrześcijańskiego (Tyniec - Kraków 2006).

Heid S., Celibat w Kościele pierwotnym (Tuchów 2000).

Jan Paweł II, Adhortacja Familiaris consortio (1981).

Jan Paweł II, Adhortacja Vita consecrata (1996).

Justyn Męczennik, 1. i 2. Apologia. Dialog z Żydem Tryfonem

(tł. L. Misiarczyk) (Warszawa 2012).

Kania W., „Doktor dziewictwa - św. Ambroży”, Vox Patrum 32-33 (1997) 133-137.

Kidd E., The Virgin Desert: Gender Transformation in Fourth-Century Christian Asceticism, http://lyceumphilosophy. com/?q=node/73 (dostęp 17.12.2015)

Klemens Aleksandryjski, Kobierce zapisków filozoficznych dotyczacych prawdziwej wiedzy (tł. J. Niemirska-Pliszczyńska) (Warszawa 1994).

Kłoczowski J., Od pustyni do wspólnoty (Warszawa 1987).

Małunowiczówna L., „Dziewica”, Encyklopedia katolicka (red. R. Łukaszyk - L. Bieńkowski - F. Gryglewicz) (Lublin 1995) IV, 604-605.

Maulard A., Saint Jean Chrysostome défenseur du marriage et apôtre la virginité (Paris 1923).

Metody z Olimpu, Uczta (tł. S. Kalinkowski) (Pisma Starochrześcijańskich Pisarzy 24; Warszawa 1980) 27-108.

Metz R., La consécration des vierges dans l'Église romaine. Etude d'histoire de la liturgie (Paris 1954).

Orygenes, Komentarz do Ewangelii wedtug Mateusza (tł. K. Augustyniak) (Źródła Myśli Teologicznej 10; Kraków 1998).

Orygenes, $O$ zasadach (tł. S. Kalinkowski) (Źródła Myśli Teologicznej 1; Kraków 1996).

Ostrowski G., „Obrona dziewicy Indycji okazją do pouczenia o cnocie dziewictwa. List św. Ambrożego do Syagriusza (Ep, 56)", Vox Patrum 52/2 (2008) 785-796. 
Špidlik T. - Tenace M. - Čemus R., Il Monachesimo secondo la tradizione dell'Oriente cristiano (Roma 2007).

Swoboda A., „Aspekty teologiczne małżeństwa i dziewictwa w pismach św. Augustyna", Śląskie Studia Historyczno-Teologiczne 37 (2004) 139-157.

Tertulian, Do żony (tł. K. Obrycki) (Pisma Starochrześcijańskich Pisarzy 29; Warszawa 1983).

Tertulian, Zachęta do czystości (tł. K. Obrycki) (Pisma Starochrześcijańskich Pisarzy 29; Warszawa 1983).

Tibiletti C., „Vergine - Verginità - Velatio”, Dizionario patristico e di antichità cristiane (red. A. di Berardino) (Casale Monferrato 1984) 3559-3563.

Bp Piotr Turzyński

Kuria Diecezji Radomskiej

ul. Malczewskiego 1

26-600 Radom

pturz@wp.pl

Bp PIOtR TurzyŃski, biskup pomocniczy diecezji radomskiej, doktor habilitowany teologii, odbył studia w Instytucie Patrystycznym „Augustinianum” w Rzymie oraz na Papieskim Uniwersytecie Gregoriańskim w Rzymie. Habilitację uzyskał na UKSW w Warszawie w 2014 r. na postawie dysertacji: Piękno w teologii świętego Augustyna. Próba systematyzacji augustyńskiej estetyki teologicznej. Sakrę biskupią przyjął 28 lutego 2015 r. w Radomiu. 
